„Bohemistyka” 2019, nr 3, ISSN 1642-9893

František VŠETIČKA

DOI: $10.14746 /$ bo.2019.3.4

Univerzita Palackého, Olomouc

\section{Sokrates Josefa Tomana}

Keywords: Josef Toman, Sokrates, architectonics, hour time, intermezzi, epistolar component, Gods' motives, significant chapter, deus ex machina, J.L. Fischer,

Klíčová slova: Josef Toman, Sokrates, architektonika, horální čas, intermezza, epistolární složka, motiv bohů, signifikantní kapitola, deus ex machina, J.L. Fischer.

\section{Abstract}

Josef Toman divided his novel Sokrates (1975) into seven parts separated by intermezzi. In the prosaic composition he used hour time, epistolary components, Gods' motives and significant chapters. A considerable role is represented by deus ex machina in the text. The work is concluded by mortal finale and paradox explicit. Toman's interpretation of the Greek philosopher is close to the one by J. L. Fischer.

Josef Toman rozvrhl svůj román Sokrates (1975) do sedmi částí, jež oddělil intermezzy. Při výstavbě své prózy použil horálního času, epistolární složky, motivu boh a signifikantní kapitoly. Nemalou roli hraje v textu deus ex machina. Mortální finále a paradoxní explicit uzavírají dílo. Tomanovo pojetí řeckého filozofa je blízké pojetí filozofa J. L. Fischera.

Josef Toman byl zasvěcený znalec řeckých a římských dějin. Bezprostřední svědectví o tom podává nejen jeho vrcholné dílo, jímž je Sokrates (1975), ale už předchozí román Po nás potopa a publicisticky zaměřená Italská paleta. Poslední titul, ze zmíněných tři však nejstarší, byl sice napsán spolu s manželkou Miroslavou, ale právě vzájemná konfrontace jejich črt a obrázků ukazuje na rozdíl mezi nimi. Miroslava Tomanová působí dojmem, exaltací, do nichž vnáší nemalý počet ideologických prvků (někdy dosti primitivních), Josef Toman naopak je znalec, důvěrně ovládá antickou historii a antický svět, je si vědom jejich pohybu, vývoje a omezení, jež přispěly k jeho zká- ze. Miroslava Tomanová přistupuje k antice zvnějšku, kdežto Josef Toman ji má v sobě, je jí prostoupen (nejnázornější svědectví o tom podává kapitola o Římě ze zmíněné Italské palety).

Toman tíhl k historickým látkám od samého počátku. Už v jeho debutu Slavnost léta z roku 1925, jenž obsahuje veršované, prozaické a dramatické texty, se nachází dramatická aktovka Srdce Kleopatřino. Hra se odehrává za panování královny Kleopatry.

Nejobsáhlejší obraz o antickém Recku podal Toman ve svém románě o Sokratovi, v němž průběžně zdůrazňuje filozofovu zásadu sófrosyné, uměřenosti, citu pro správnou míru. Sokratovo pravidlo bylo pro Tomana natolik závažné a závazné, že se jej přidržel i při výstavbě svého románu. Svědčí o tom nejen celková architektonika díla, ale i další jeho stavebné prostředky (horální čas, intermezza, epistolární složka ad.).

Tomanův Sokrates se skládá z prologu, sedmi částí a čtyř intermezz. Stěžejní př́iběh o Sokratovi vložil autor do sedmice částí. Funkce prologu a intermezz je poněkud jiná.

V prologu se Sokrates narodí. Začátku díla tak odpovídá začátek života. Sokrates se narodí v pravé poledne. Švec Leptinés to komentuje slovy:

A přišel na svět zrovna ve chvíli, kdy je Hélios na vrcholu!

Poledne by napovídalo št'astný osud zrozence, předjetí tohoto druhu je však problematické.

A totéž poledne se objeví v závěrečné fázi díla, v době soudu nad Sokratem. Filozof se před soudem dobře obhájí, ale v závěru obhajoby přistoupí na to, že zopakuje tanec, který předvedl kdysi dávno na agoře před sochou bohyně Athény. Tanec se mu pro př́lišné vedro nezdaří, je totiž právě zase poledne:

Nad Sokratem stojí polední slunce, slunce, které vystoupilo nejvýš na nebeské dráze. Totéž slunce, pod nímž se před sedmdesáti lety narodil. - Jaký je to krásný okamžik, poledne! Vrchol dne, kdy nikde není stín.

\footnotetext{
${ }^{1}$ Cituji z l. vydání: Josef Toman, Sokrates, Praha, Československý spisovatel 1975.
} 
Tímto poledním sluncem Sokrates svou při prohraje. Na začátku románu a na konci tak hraje důležitou roli polední čas, který se ukáže jako čas zlovolný. Polední čas tvoří součást času horálního.

Vedle horálního času uplatňuje Toman také čas narozeninový, dies natalis. Kněžka v Delfách prohlásila Sokrata za nejspravedlivějšího a nejmoudřejšího a athénský lid se o tom dozví v den, kdy Timandra slaví své čtrnácté narozeniny. Tento dies natalis je však závažný spíše pro Alkibiada, který se v Sokratově doprovodu do čtrnáctileté zamiluje. Vedle času hodiny pracuje Toman rovněž s časem dne, význačného dne, jenž osudově zasáhne do života Alkibiadova a Timandřina.

Architektonickou zvláštností jsou dále intermezza, jež navzájem oddělují první čtyři části. Na rozdíl od ostatního románového děje v nich Sokrates rozmlouvá s autorem Josefem Tomanem. Je to rozhovor přes hranici čtyřiadvaceti století (,Jsem o čtyřiadvacet století starší než ty," směje se Sokrates Tomanovi do očí). Od chvíle, kdy se začíná Sokratův osud završovat, přestává autorova laškovná rozmluva s filozofem, jinak řečeno přestávají intermezza.

O rozmluvu s dávnými představiteli se Toman pokusil už dř́ve v Italské paletě, kde promlouval dokonce s císařem Tiberiem (v kapitole Rozhovor s císařem).

První intermezzo v románu o Sokratovi má ještě jednu funkci- vymezuje čas, dokonce dlouhé časové údobí. Hned z první věty prvního intermezza se čtenář dovídá, že mezi první a druhou částí uplynulo dvacet pět let, celé čtvrtstoletí. Jde o obrovský syžetový přeryv, v podstatě o předěl mezi mládím a dospělostí Sokrata.

Počáteční fáze Tomanova románu zahrnuje ještě jednu tektonickou zvláštnost, je jí epistolární složka. Autor ji použil v 3. kapitole druhé části - švec Leptinés formou dopisu podává svým prŕibuzným zprávu o životě v Athénách a o Sokratovi. Podobně jako intermezza má i tento list dělící, vymezovací charakter, nebot' v předchozí kapitole umírá vládce Periklés, končí se slavná éra Periklova a částečně i neméně slavné údobí demokratických Athén. Epistolární složky použil Toman výjimečně, tento žánrový prvek nemá v románě pokračování (stejně jako od jisté chvíle nepokračují ani intermezza).
A ještě jeden stavebný činitel se $v$ průběhu děje vytrácí - je jím motiv (spíše motivický prvek) bohů. Tento motiv začíná už v prologu, vlastně už v incipitu: „Bohyně se usmívala”. V prologu se navzájem hašteří bůh Mómos a bohyně Artemis. V dalším nejbližším textu má motiv pokračování - následné varianty se objevují v 11. kapitole první části a posléze v 15. kapitole druhé části, kde se už vyskytuje Mómos sám bez Artemidy. Variantou z druhé části také motiv bez jakékoliv další návaznosti končí, nejde tedy o motiv, ale o jeho torzo. Vytrácí se podobně jako vkládaná intermezza a jako epistolární složka. Jde v podstatě o ohlas, o vzdálený ohlas Tomanova Slovanského nebe, toho prozaického i dramatického, v nichž vystupovalo božstvo starých Slovanů.

Toman je dále autor, který klade důraz na signifikaci kapitol, $\mathrm{v}$ daném př́ípadě na tradiční kapitolu trrináctou. $\mathrm{V}$ této kapitole první části se Sokrates po návratu z vojny dozví, že otec Sófroniskos a matka Fainareté zemřeli na zimnici a jeho láska Korinna, že je vdaná a má už dítě. Dolehne tak na něj současně hned trojí pohroma.

Obdobně je tomu v 13. kapitole poslední části, kde Sokrates $\mathrm{s}$ konečnou platností zavrhne možnost svého útěku z vězení. Konstatuje to slovy: „Má smrt bude poslední poučení vám všem.” V obou prrípadech tak Toman naplňuje nejen sémantiku nešt'astného čísla, ale také sémantiku signifikantní kapitoly a románové architektury.

Součástí této architektury jsou i koncovky jednotlivých částí, jež Toman náležitě akcentuje. V poslední kapitole druhé části poprvé zachytil sezení athénských oligarchů, nepřátel demokracie. Mezi ně poprvé přijde Kritiás, dosavadní Sokratův žák, který tímto činem zradí nejen svého učitele, ale i věc athénské demokracie.

I koncovka třetí části má zrazující charakter, zrada jednoho jako by zplodila zradu druhého. V koncovce třetí části Alkibiadés zradí Athény, přeběhne na stranu nepřátelské Sparty a táhne s ní proti rodnému městu. Poslední dvě slova třetí části představuje jednoznačné sousloví Alkibiadova zrada.

Koncovka čtvrté části má mortální ráz. Celá část zahrnuje devět kapitol - v osmé je zrádně zabit Alkibiadés, $\mathrm{v}$ deváté padne $\mathrm{v}$ bitvě tyran Kritiás a je obnovena athénská demokracie. 
V koncovce páté části je Sokrates předvolán před héliaiu, před soud, protože je nařčen, ,že neuznává státem uznávané bohy a zavádí jiná, nová božstva, dále pak, že kazí mládež”. Od tohoto okamžiku až do konce románu je Sokrates v neustálém ohrožení. A do konce díla je více než sto stran, které líčí osočování a strasti filozofa. Po této části, podobně jako po dalších, nenásleduje už žádné intermezzo.

V koncovce šesté části je Sokrates odsouzen k trestu smrti otrávením. Výkon trestu je sice o měsíc odložen, šestá část však přesto vyznívá deziluzívně.

V koncovce šesté části přiběhne posel a přinese zprávu archontu králi, že se objevila „znamení a věštba př́íznivá k plavbě státní lodi, která byla připravena se slavnostním poselstvem vyplout na Délos k výročním oslavám Apollónovým". Během těchto oslav a plavby lodi nesměly být vykonávány žádné popravy, proto se trest Sokratovy smrti odkládá. Jde o zásah vyšší moci, ale problematický, poněvadž výkon trestu pouze oddalující. Posel je v tomto případě deus ex machina a ztělesňuje tak stavebný prostředek antického původu, což plně odpovídá antické tematice díla.

Ve finále románu zachycuje Toman Sokratovu smrt. Do jisté míry je jím samým vědomě přijatá, nebot' jeho přátelé učinili vše, aby mohl uprchnout. Sokrates to odmítl.

Způsob, jakým se vzdává možnosti útěku, představuje v konfrontaci s argumentací jeho zasvěcených přátel vyvrcholení jeho filozofického uvažování. Kulminační bod pak ztělesňuje filozofická půtka mezi Sokratem a Platónem, která vyústí do toho, že Sokrates musí zůstat. Závěrečné partie románu jsou tak dokladem toho, že si Toman osvojil způsob filozofova myšlení. Autor se zde ztotožnil se svým fiktivním, a zároveň nefiktivním hrdinou.

Sokratovým následovníkem a zapisovatelem jeho myšlenek se stal Platón. Proto také tento filozof vystupuje v závěrečné fázi díla do popředí. Ve finální části jsou mu dokonce věnovány samostatné kapitoly, konkrétně 10 . a 11., kde vystupuje převážně sám a kde jsou také postulovány jeho filozofické názory.
Román uzavírá Toman explicitem, jenž je vysloveně paradoxní. V okamžiku nadcházející smrti Sokrates totiž promlouvá o opaku, o nezbytnosti života: „V každém člověku je slunce - jenom je nechat plát..." Sokrates reaguje jako filozof.

Paradoxní je nejen explicit románu, ale také autorství díla. Próza vyšla roku 1975 a 27. ledna 1977 Josef Toman skonal. Ještě téhož roku byl vydán Sokrates podruhé a opět s autorovým jménem. Za dva roky nato (1979) vyšel slovenský překlad tohoto románu a poprvé také se jménem Tomanovy manželky Miroslavy. První vydání Sokrata navíc obsahovalo Tomanův doslov, v němž se rozepisoval o tom, jak studoval prameny, jak dílo koncipoval a tvořil. Žádné další vydání tento doslov neobsahuje. Rovnocenné spoluautorství Miroslavy Tomanové je značně nepravděpodobné, což mimo jiné dokazuje její jediný román Střibrná plán̆, zachycující osudy příslušníků Svobodovy armády za druhé světové války. Výstavba tohoto díla je nesouměřitelná s poetikou románu o Sokratovi.

Josef Toman přistupuje k Sokratově osobě a k historii Athén z marxistických pozic, což sám v doslovu k prvnímu vydání přiznává. Jeho podrobné líčení společenského nešváru a zejména obšírné a zdlouhavé podání soudu nad filozofem nezbytně připomíná represivní postupy v tehdejším Československu. Vždyt' právě takovým způsobem byla za normalizace, kdy román vyšel, likvidována elita národa. Byl to Tomanův záměr, nebo je to bezděčnost? Josef Toman byl sice roku 1970 poctěn titulem zasloužilého umělce a roku 1974 dokonce titulem národního umělce, na druhé straně nelze však pominout, že byl zároveň člověk a umělec vidoucí. V předválečném období byl spolupracovníkem Vladislava Vančury, jehož tvorba jej do značné míry ovlivnila. S Vančurou je navíc spjat pojetím historické prózy. Autor Obrazů z dějin národa českého tímto dílem za okupace domácího čtenáře posiloval a povzbuzoval, př́buznou tendenci lze vysledovat i v Tomanově Sokratovi, který vznikal za okupace pozdější. Paralela mezi Vančurou a Tomanem není tak docela náhodná. ${ }^{2}$

\footnotetext{
${ }^{2} \mathrm{~V}$ této souvislosti třeba dodat, že Blahoslav Dokoupil, autor hesla o Josefu Tomanovi v Lexikonu české literatury posuzuje jeho román negativně: „V 70. letech
} 
Josef Toman ve svém doslovu uvádí pouze dva zdroje, z nichž čerpal a jimiž se nechal inspirovat - Platóna a Xenofónta. Autor však nejspíše vycházel i z jiných pramenů, soudobých. V poválečném období se Sokratovou osobností a jeho názorovým světem zabývali dva čeští filozofové, v normalizačním období nežádoucí. Prvním z nich byl Jan Patočka, jehož práce o Sokratovi vyšla už roku 1947, ale pouze jako skripta. Knižně byla vydána teprve roku 1991. Toto dílo Toman s největší pravděpodobností neznal. Naopak se patrně seznámil s prací J.L. Fischera, nazvanou Sokrates nelegendární, pocházející z roku 1965. Fischer, podobně jako Patočka, patřil v sedmdesátých letech k zakázaným a druhé vydání jeho Sokrata z roku 1970, jež připravil ostravský Profil, šlo proto do stoupy. Zachovalo se jen několik exemplářů. Toman se o Fischerově Sokratovi nezmiňuje, ale oba - filozof i romanopisec - kladou důraz na jeho introvertnost jako na hlavního hybatele filozofovy aktivity. ${ }^{3}$ Je velmi pravděpodobné, že neoficiální J.L. Fischer podstatným způsobem ovlivnil pojetí tehdy oficiálního Josefa Tomana. Cesty sófrosyné jsou nevyzpytatelné.

\section{Literatura}

Toman J., 1975, Sokrates. Praha: Československý spisovatel.

Hrušovský I., 1965, Nový pohlad na Sokrata. „Otázky marxistickej filozofie” 20, s. 665 .

Fischer J. L., 1970, Sokrates nelegendární. Ostrava: Profil.

Lexikon české literatury 4, 2008, svazek 1, Praha: Academia.

Všetička Fr., 2017, Slovesné sondy. Jinočany: H\&H.

Všetička Fr., 2018, Energie Ephialta. Praha: Cherm.

vyšel vstříc oficiální koncepci literatury a požadované prezentaci kladných vzorů pojetím řeckého filozofa Sokrata jako člověka zosobňujícího moudrost a harmonii a předchůdce novodobých myšlenek sociální rovnosti" (Lexikon české literatury... 2008, s. 943-944).

${ }^{3} \mathrm{Na}$ tuto přednost Fischerovy publikace poukázal už slovenský filozof Igor Hrušovský (1965, s. 665). 